\title{
Modeling Canopy Carbon and Water Fluxes Using a Multilayered Model over a Temperate Meadow in Inner Mongolia
}

\author{
Nina Chen ${ }^{1} \cdot$ Anzhi Wang ${ }^{2} \cdot$ Juan $\mathrm{An}^{3} \cdot$ Yushu Zhang ${ }^{1} \cdot$ Ruipeng $\mathrm{Ji}^{1} \cdot$ Qingyu Jia ${ }^{1} \cdot$ Ziqi Zhao $^{1} \cdot$ Dexin Guan ${ }^{2}$ (D)
}

Received: 26 March 2019 / Accepted: 18 October 2019 / Published online: 28 October 2019

(c) The Author(s) 2019

\begin{abstract}
To incorporate canopy vertical structure in a process-based model over a temperate meadow, a multilayered model estimated canopy carbon flux $\left(F_{\mathrm{c}}\right)$ and water flux $(L E)$ was applied by comparing with eddy covariance measurements in Inner Mongolia, China. Simulations of diurnal, seasonal $\mathrm{CO}_{2}$ and $\mathrm{H}_{2} \mathrm{O}$ fluxes and model sensitivity to parameters and variables were analyzed. The results showed that the model underestimated $F_{\mathrm{c}}$ and $L E$ by about $0.6 \%$ and $5.0 \%$, respectively. It was able to simulate the diurnal and seasonal variation of $F_{\mathrm{c}}$ and $L E$ and performed well during the day and in the growing season, but poorly at night and early in the growing season. $F_{\mathrm{c}}$ was more sensitive to the leaf nitrogen content distribution coefficient and maximum catalytic activity of Rubisco, whereas $L E$ showed greater sensitivity to the stomatal conductance parameter $a_{1}$, empirical coefficient of stomatal response to saturated vapor pressure difference $\mathrm{V}_{\mathrm{pds} 0}$, and minimum stomatal conductance of $\mathrm{CO}_{2} g_{\mathrm{sc} 0}$. The response of $F_{\mathrm{c}}$ to environmental factors was ranked as air $\mathrm{CO}_{2}$ concentration $\left(C_{\mathrm{a}}\right)>$ air temperature $\left(T_{\mathrm{a}}\right)>$ photosynthetically active radiation (PAR) $>$ soil water content $\left(\theta_{\mathrm{sm}}\right)>$ vapor pressure deficit $(\mathrm{VPD})>$ wind speed $\left(u_{0}\right)$. The response of $L E$ to environmental factors was ranked as $T_{\mathrm{a}}>\mathrm{VPD}>\theta_{\mathrm{sm}}>\mathrm{PAR}>C_{\mathrm{a}}>u_{0}$. The response of $L E$ to vegetation characteristic parameters was greater than that of $F_{\mathrm{c}}$.
\end{abstract}

Keywords Carbon and water exchange $\cdot$ Ecological modeling $\cdot$ Eddy covariance $\cdot$ Multilayered model $\cdot$ Sensitivity analysis

\section{Introduction}

Exchange of carbon and water fluxes between the atmosphere and vegetation depend on complex and non-linear interplay among physiological, ecological, biochemical, and edaphic factors and meteorological conditions (Huang et al. 2016; He et al. 2017; Fell et al. 2018). Direct observation of many variables associated with energy transfer and material circulation is difficult on a large scale. The most common

Dexin Guan

251926732@qq.com; dxguan@iae.ac.cn

1 Liaoning Provincial Key Laboratory of Agricultural Meteorological Disasters, Institute of Atmospheric Environment, China Meteorological Administration, Shenyang 110166, China

2 State Key Laboratory of Forest and Soil Ecology, Institute of Applied Ecology, Chinese Academy of Sciences, Shenyang 110016, China

3 Shandong Provincial Key Laboratory of Water and Soil Conservation and Environmental Protection, College of Resources and Environment, Linyi University, Linyi 276000, China models for estimation of carbon and water fluxes are statistical models (Shen et al. 2011) and comprehensive processbased coupled carbon and water models (Leuning et al. 1995; Wang and Leuning 1998). The advantages of a statistical model are that it is simple in form and easy to derive. But it is more empirical and difficult to extrapolate to other regions. The physical interpretation is unclear and a statistical model lacks predictive power. A process-based carbon and water flux coupling model has a clear mechanism. The combination of plant physiological characteristics, canopy structure, soil characteristics, and climatic variables has a certain theoretical basis and clear physical meaning. Such a model not only simulates carbon and water fluxes at the single-leaf scale (Yu et al. 1998), but can be extended to canopy (Sellers et al. 1992) and ecosystem scales (Leuning et al. 1995; Wang and Leuning 1998), and even to regional scales (McMurtrie et al. 1992) and some global climate models (Sellers et al. 1996).

Process-based coupled carbon and water flux models are based on soil-plant-vegetation-atmosphere transfer interactions and include big-leaf, two-leaf, and multilayered models. A multilayered model considers parameters measured 
at the leaf scale and the spatial distribution of vegetation physiological parameters as well as climatic variables, and integrates the fluxes of each layer to derive the total fluxes. Thus, a multilayered model is considered to be reasonable and has been employed in many studies (Leuning et al. 1995; Shi et al. 2010; Qu and Zhao 2016).

Mongolian grasslands are sensitive to climate change and human activities. The Mongolian steppe is located between Siberian coniferous forest and the Asian Gobi Desert. Significant changes in temperature, precipitation, and other climatic variables, and increased grassland degradation and desertification are predicted for the future (IPCC 2001). Meadow, the most productive type of grassland supporting livestock production, is located in the eastern part of Inner Mongolia (Liao and Jia 1996). Meadow steppe constitutes $11 \%$ of the $7.88 \times 10^{5} \mathrm{~km}^{2}$ of native grassland in Inner Mongolia (Han et al. 2008). Approximately $80 \%$ of the plant biomass in meadow steppe is composed of Phragmites australis, Leymus chinensis, Glycine soja, Plantago asiatica, and Ranunculus microphyllus. Extensive variability in photosynthetic parameters of these species lead to differences in photosynthesis productivity (Wullschleger 1993; Chen et al. 2014), thus influencing the carbon and water exchange of grassland ecosystems. In addition, each species occupies a different height within the canopy and hence shows a different competitive ability for solar radiation (Xue et al. 2017; Zhao et al. 2018). Consequently, canopy vertical structure is more difficult to incorporate in a carbon and water fluxes model for meadow (Chang et al. 2018). The majority of previous studies focused on vegetation composed of a single species (Leuning 1995) or vegetation types other than grassland (Kucharik et al. 2006; Shi et al. 2010). To the best of our knowledge, no previous study has modeled canopy carbon and water fluxes for a mixed-species meadow.

In this paper, a multilayered model estimated canopy carbon and water fluxes was applied over a temperate meadow. It was tested by comparing simulated $\mathrm{CO}_{2}$ and $\mathrm{H}_{2} \mathrm{O}$ fluxes with eddy covariance measurements across half-hour to three-year time scales firstly. And then, the sensitivity of the model to physiological, environmental, and vegetation characteristic parameters were analyzed.

\section{Materials and Methods}

\section{Model Description}

The model used in this paper was developed by Leuning et al. (1995), tested on a wheat crop canopy by Leuning et al. (1998), and revised for a mixed forest by Shi et al. (2010). The multilayered model at the canopy scale included four components: radiation absorption, coupling of a single-leaf stomatal conductance-energy balance-photosynthetic model, spatial distribution of physiological parameters, and integration of space and time.

In this paper, the canopy radiation absorption, coupling of a single-leaf stomatal conductance-energy balance-photosynthetic model, and spatial distribution of physiological parameters were similar to those of the previous studies (Leuning et al. 1995; Shi et al. 2010), whereas the integration of space and time was revised to be compatible with meadow steppe vegetation.

\section{Canopy Radiation Absorption}

Radiation absorbed by sunlit leaves $\left(Q_{\mathrm{sl}}\right)$ is expressed as (Leuning et al. 1995):

$Q_{s l}(\xi)=Q_{l b}+Q_{s h}(\xi)$

where $\xi$ is the cumulative leaf area index measured from the top of the canopy downwards, $Q_{\mathrm{lb}}$ is the diffuse radiation absorbed by all leaves at canopy depth $\xi$, and $Q_{\mathrm{sh}}$ is the radiation absorbed by shaded leaves.

$Q_{\text {sh }}$ is estimated by the formula:

$Q_{s h}(\xi)=Q_{l d}^{\prime}(\xi)+Q_{l b s}(\xi)$

where $Q_{\mathrm{ld}}^{\prime}$ and $Q_{\mathrm{lbs}}$ are the absorbed components of incoming diffuse and scattered beam radiation, respectively, and are associated with the extinction coefficient for radiation and the leaf area index (Goudriaan and van Laar 1994).

\section{Coupling of Single-Leaf Stomatal Conductance-Energy Balance-Photosynthetic Model}

Stomatal and Boundary Layer Conductance Model Total conductance of $\mathrm{CO}_{2}\left(g_{\mathrm{tc}}\right)$ and $\mathrm{H}_{2} \mathrm{O}\left(\mathrm{g}_{\mathrm{tw}}\right)$ from the substomatal cavities to the air outside the leaf boundary layer are calculated as:

$g_{t c}=\frac{1}{1 / g_{s c}+1 / g_{b c}}$

$g_{t w}=\frac{1}{1 / g_{s w}+1 / g_{b w}}$

The stomatal conductance of $\mathrm{CO}_{2}\left(g_{\mathrm{sc}}\right)$ is calculated as (Leuning 1995):

$g_{s c}=g_{s c 0}+\frac{a_{1} \cdot f_{s m} \cdot A_{n}}{\left(C_{s}-\Gamma^{*}\right) \cdot\left(1+V p d_{s} / V p d_{s 0}\right)}$

where $A_{\mathrm{n}}$ is the $\mathrm{CO}_{2}$ assimilation rate, $g_{\mathrm{sc} 0}$ is the minimum stomatal conductance of $\mathrm{CO}_{2}$ when $A_{\mathrm{n}}=0$ at the light compensation point, $C_{\mathrm{s}}$ is the $\mathrm{CO}_{2}$ concentration, $\Gamma^{*}$ is the $\mathrm{CO}_{2}$ compensation point, and the parameter $a_{1}$ is associated 
with the intercellular $\mathrm{CO}_{2}$ concentration $\left(C_{\mathrm{i}}\right)$ at saturating irradiance as determined by the relationship $1 / a_{1}=1-C_{\mathrm{i}} /$ $C_{\mathrm{s}}$ (Leuning et al. 1995). The function $f_{\mathrm{sm}}$ reflects the soil moisture limit $\left(\theta_{\mathrm{sm}}\right)$ on stomatal conductance (Stewart and Verma 1992), $\operatorname{Vpd}_{\mathrm{s}}$ is the vapor pressure saturation deficit, and $\mathrm{Vpd}_{\mathrm{s} 0}$ is the empirical coefficient of stomatal response to saturated vapor pressure difference.

The boundary layer conductance of $\mathrm{CO}_{2}\left(g_{\mathrm{bc}}\right)$ is proportional to the boundary layer conductance of water vapor $\left(g_{\text {bw }}\right)$ as:

$g_{b c}=g_{b w} /(1.37 \cdot m)$

where the constant 1.37 is the ratio of diffusivity of $\mathrm{CO}_{2}$ and water vapor in the boundary layer (Von Caemmerer and Farquhar 1981), and $m$ is the molar volume of gas that is required to convert $g_{\mathrm{bc}}$ from velocity to molar units.

The boundary layer conductance of water vapor $\left(g_{\text {bw }}\right)$ is associated with its thickness and the molar diffusivity of water vapor $\left(D_{\mathrm{w}}\right)$ in air:

$g_{b w}=D_{w} / B_{t}$

where $B_{\mathrm{t}}$ is the boundary layer thickness (Aphalo and Jarvis 1993). $D_{\mathrm{w}}$ is calculated as described by Amthor (1994) from the air temperature $\left(T_{\mathrm{a}}\right)$.

The stomatal conductance of $\mathrm{H}_{2} \mathrm{O}\left(g_{\text {sw }}\right)$ is calculated as (Leuning 1995):

$g_{s w}=1.56 \cdot g_{s c} \cdot m$

where the constant 1.56 is the ratio of molecular diffusivity for water vapor and $\mathrm{CO}_{2}$ in air (Leuning et al. 1995).

\section{Leaf Energy-Balance Model}

Net radiation absorbed by the leaves is divided into sensible and latent heat. The Penman-Monteith equation is used to calculate latent heat (Leuning et al. 1995), whereas the sensible heat is calculated by the energybalance model:

$L E=\frac{s \cdot Y \cdot R_{n}^{*}+\rho_{a} \cdot c_{p} \cdot V p d_{a} \cdot g_{b h}}{s \cdot Y+\gamma \cdot g_{b h} / g_{t w}}$

$H=Y \cdot\left(R_{n}^{*}-L E\right)$

where $R_{n}^{*}$ is the net isothermal radiation absorbed by the leaf, $Y$ is a coefficient associated with radiation conductance (Leuning et al. 1995), $L E$ and $H$ are the latent and sensible heat exchanges between a leaf and its surroundings, respectively, $\rho_{\mathrm{a}}$ is the air density, $\operatorname{Vpd}_{\mathrm{a}}$ is the vapor pressure saturation deficit in air, and $c_{\mathrm{p}}$ is the specific heat capacity of dry air.

\section{Leaf Photosynthesis Model}

Farquhar et al. (1980) presented a biochemical model of photosynthetic carbon assimilation in $\mathrm{C}_{3}$ plants:

$A_{n}=\min \left\{A_{v}, A_{j}\right\}-R_{d}$

where $\min \{\}$ denotes 'minimum of', $A_{\mathrm{v}}$ is ribulose bisphosphate carboxylase-oxygenase (Rubisco) activity, $A_{\mathrm{j}}$ is the ribulose bisphosphate $\left(\mathrm{RuP}_{2}\right)$ regeneration rate allowed by electron transport, and $R_{\mathrm{d}}$ is 'dark respiration' (defined as the $\mathrm{CO}_{2}$ evolved other than through the photorespiratory pathway). $R_{\mathrm{d}}$ is proportional to the maximum catalytic activity of Rubisco $\left(V_{\text {cmax }}\right)$, following (Farquhar et al. 1980):

$R_{d}=0.0089 \cdot V_{c \max }$

Given that $A_{\mathrm{n}}, L E$ and $g_{\mathrm{sc}}$ are not independent, the values of $C_{\mathrm{i}}$ and $g_{\mathrm{sc}}$ must be determined in an iterative fashion. The model is operated in accordance with the method of Shi et al. (2010).

\section{Spatial Distribution of Physiological Parameters}

In parameterizing multilayered models, physiological and environmental characteristics should change with depth in the canopy, and sunlit and shaded leaves should be treated separately. The distribution of key environmental and plant factors at different canopy depths $(\xi)$, wind speeds $(u)$, and $V_{\text {cmax } 0}$ are estimated as follows (Leuning et al. 1995):

$u(\xi)=u_{0} \cdot \exp \left(-k_{u} \cdot \xi\right)$

$V_{c \max }=V_{\text {cmtop }} \cdot\left(-k_{n} \cdot \xi / \xi_{t}\right)$

where $u_{0}$ is the wind speed above the top of the canopy, $V_{\text {cmtop }}$ is the value of $V_{\text {cmax }}$ at $\xi=0, \xi_{\mathrm{t}}$ is the total leaf area index, $k_{\mathrm{u}}$ is the extinction coefficient for wind speed, and $k_{\mathrm{n}}$ is the distribution coefficient for leaf nitrogen.

\section{Integration of Space and Time}

To apply the model to a temperate meadow composed of mixed species, we adjusted the method of dividing the canopy into multilayers. The total canopy thickness of the meadow is about $1.2 \mathrm{~m}$ based on the results of a field survey in the vicinity of the flux tower (Chen et al. 2014). The canopy is divided into 12 layers based on the vertical distribution of the dominant species.

The photosynthesis rate $A_{\mathrm{c}}(t)$ and transpiration rate $L E_{\mathrm{c}}(t)$ of each layer of the canopy of one species at time $t$ are calculated as:

$A_{c}(t)=\sum_{i=1}^{n}\left[A_{s b} f_{s l}+A_{s h} f_{s h}\right] X$ 
$L E_{c}(t)=\sum_{i=1}^{n}\left[L E_{s l} f_{s l}+L E_{s h} f_{s h}\right] X$

where $A_{\mathrm{sl}}$ and $A_{\mathrm{sh}}$ are the assimilation rates of sunlit and shaded leaves, respectively, of each species, $f_{\mathrm{sl}}$ and $f_{\mathrm{sh}}$ are the fractions of sunlit and shaded leaf areas, $L E_{\mathrm{sl}}$ and $L E_{\mathrm{sh}}$ are the evapotranspiration rates of sunlit and shaded leaves of each species, $\left[A_{\mathrm{s}} f_{\mathrm{sl}}+A_{\mathrm{sh}} f_{\mathrm{sh}}\right]$ is the assimilation rate of one layer, $\left[L E_{\mathrm{s}} f_{\mathrm{sl}}+L E_{\mathrm{sh}} f_{\mathrm{sh}}\right]$ is the evapotranspiration rate of one layer, $n$ is the total number of layers (12), $X$ is the proportion of biomass in a layer of a certain species. Finally, $A_{\mathrm{c}}(t)$ and $L E_{\mathrm{c}}(t)$ at each point of the canopy of each species are respectively summed, which is the net photosynthesis rate $A_{\mathrm{n}}$ and the evapotranspiration rate $L E_{\mathrm{c}}$ of the grass canopy at that time point.

\section{Studied Location}

The experiment was carried out in a meadow of Horqin Grasslands in Horqinzuoyihou County, eastern Inner
Mongolia, China (as shown in Fig. 1). A measurement tower $4 \mathrm{~m}$ in height was established at the study site $\left(43^{\circ} 17^{\prime} 37^{\prime \prime} \mathrm{N}, 122^{\circ} 16^{\prime} 42^{\prime \prime} \mathrm{E}, 203 \mathrm{~m}\right.$ altitude). The site experiences a temperate continental climate, cold and dry in the dormant season, and relatively warm and wet in the growing season. The mean annual precipitation is $378.8 \mathrm{~mm}$, and the annual mean air temperature is $6.2^{\circ} \mathrm{C}$.

Approximately $80 \%$ of the plant biomass at the study site was composed of Phragmites australis, Leymus chinensis, Glycine soja, Plantago asiatica, and Ranunculus microphyllus. The average height of the vegetation was $0.45 \mathrm{~m}$ in the mid-growing season from June to August. The grass at the study site is harvested for livestock forage in September. The field is flat and characterized by the Haplumbrepts soil type (USDA Taxonomy). Soil organic matter content is $8-10 \%$, soil depth is $40-100 \mathrm{~cm}$, and soil $\mathrm{pH}$ is $8.5-10.5$.

Fig. 1 Map of site's location

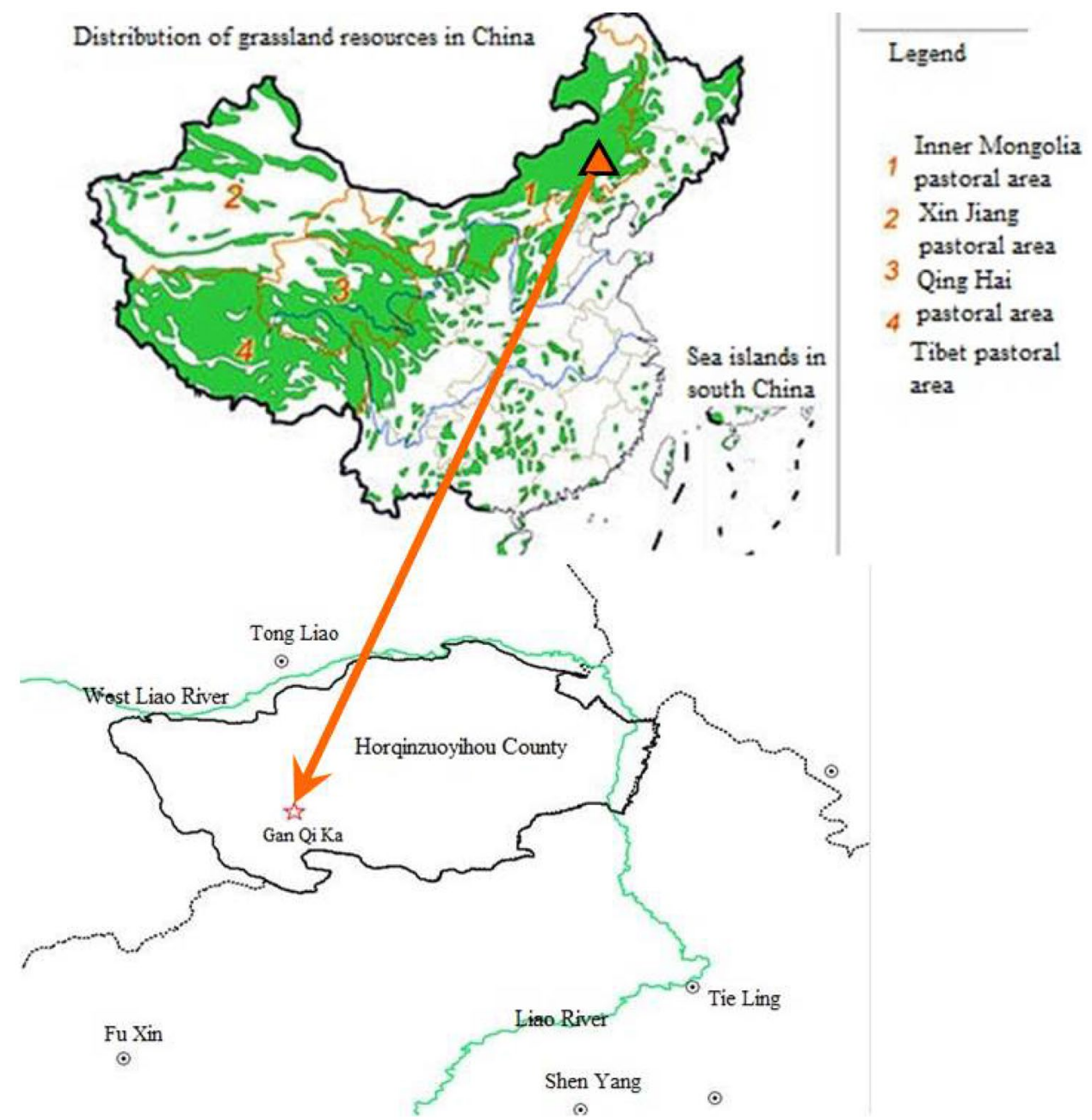




\section{Observed Data Collection}

\section{Microclimate and $\mathrm{CO}_{2} / \mathrm{H}_{2} \mathrm{O} /$ Energy Flux Measurements}

Eddy covariance and microclimatic instruments were installed on the meteorological tower at the experimental site and have been in operation since August 2007. Eddy covariance, routine meteorological, and solar radiation instruments were installed on the meteorological tower in the meadow. Details of the instrumentation are presented in Table 1. Original signals from the eddy covariance system were sampled at $10 \mathrm{~Hz}$, whereas data from the other instruments were collected at $0.5 \mathrm{~Hz}$. All of the above-mentioned meteorological data were stored as 30-min averages.

\section{Photosynthetic Parameters of Dominant Species}

To quantify photosynthetic parameters, such as $V_{\text {cmax }}$, photosynthetic characteristics of the five dominant species were measured in 2010 and 2011 with a LI-6400 portable photosynthesis system (LiCor Inc., Lincoln, NE, USA) equipped with an artificial irradiance source (LiCor 6400-02B red/ blue LED light source) and a $\mathrm{CO}_{2}$ concentration source (LiCor 6400-01 $\mathrm{CO}_{2}$ mixer; Chen et al. 2014).

\section{Measurement of Leaf Area Index}

Leaf area index was measured by a plant canopy analyzer (LAI-2000, LiCor Inc., Lincoln, NE, USA). The observation site was selected as a cross section of about $200 \mathrm{~m}$ long in the southwest of the flux tower, and 12 points were selected before sunrise or after sunset, or on cloudy days. In the early
(May) and end (September) growing seasons, the leaf area index is observed every 3-5 days, while every 5-10 days during the mid growing season (June-August).

\section{Measurement of Soil Evaporation}

Six small lysimeters ( $30 \mathrm{~cm}$ in height), constructed of PVC, were consisted of outer tubes with diameter of $12 \mathrm{~cm}$ and inner tubes with diameter of $10 \mathrm{~cm}$. Lysimeters No. 1, 2, and 3 were placed under the grass canopy, and No. 4, 5, and 6 were placed in a grass-free plot nearby (area $1 \mathrm{~m} \times 2 \mathrm{~m}$, in which the grass was cut every few days to ensure the plot was grass-free). The outer tube was fixed in the soil so that the surface was level with the neighboring soil to avoid damage to the nearby soil structure during operation. When preparing the undisturbed soil, the bottomless lysimeter inner cylinder was vertically pressed into the soil, leaving $0.5 \mathrm{~cm}$ of the tube exposed above the soil surface. The inner cylinder containing the undisturbed soil was dug out, and the excess soil at the bottom of the cylinder was excised so that the bottom surface of the cylinder was flat. The bottom surface of the inner cylinder was sealed with a bottom cover with micro holes. The cylinder was weighed at 30-min intervals using a load cell (model 203A, Wuhan Lihe Electric Meter Factory, Wuhan, China). To ensure that the soil moisture content in the lysimeter was similar to that of the surrounding soil, the undisturbed soil in the lysimeter was replaced every 5-7 days.

\section{Calibration Phase}

Numerical solution method was used in the process:

Table 1 Introduction of eddy covariance, routine meteorological and solar radiation measurements

\begin{tabular}{lll}
\hline Type of measurements & Instrument & Heights \\
\hline Routine meteorological measurement system & & $1.5 \mathrm{~m}$ and $3 \mathrm{~m}$ \\
$\begin{array}{l}\text { Air temperature and relative humidity } \\
\text { Precipitation }\end{array}$ & HMP45C, Vaisala, Helsinki, Finland & $1 \mathrm{~m}$ \\
Photosynthetically active radiation & TE525MM, Campbell Scientific, Inc., USA & $1.5 \mathrm{~m}$ \\
Net radiation & LI190SB, LiCor Inc., USA & $1.5 \mathrm{~m}$ \\
Soil moisture & NR-LITE, Kipp\&Zonen, Delft, Netherlands & 5 and $20 \mathrm{~cm}$ below ground \\
Soil temperature & CS616, Campbell Scientific, Inc., USA & $0,5,10$ and $20 \mathrm{~cm}$ below ground \\
Soil heat flux & Modell09, Campbell Scientific, Inc., USA & $5 \mathrm{~cm}$ below ground \\
Eddy covariance system & HFP01, HukseFlux, Netherlands & $3 \mathrm{~m}$ \\
Latent heat flux & & CSAT3, Campbell Scientific, Inc., USA \\
Sensible heat flux & Li-7500, Licor Inc., Nebraska, USA & Surface \\
Power supply equipment & & \\
Solar panels & T160W, Suntech Power Co. Ltd., China \\
Data logger & & \\
Data collector and & ModelCR1000, Campbell Scientific, Logan, UT, USA \\
communication & & \\
\hline
\end{tabular}


1. Give $g_{\mathrm{sc}}$ a small initial value, such as 0.1 ;

2. Simulate the stomatal conductance and boundary layer conductance under the condition of $g_{\mathrm{sc}}$, and obtain the conductance of each resistance segment;

3. Substituting the obtained conductance into the energy balance equations to calculate the leaf temperature $\left(T_{1}\right)$, latent heat flux $(L E)$ and sensible heat flux $(H)$;

4. Substituting the calculated $T_{1}$, and a given $C_{\mathrm{i}}$ value into the photosynthesis model, calculate the net photosynthesis rate $A_{\mathrm{n}}$ at this time. Calculate a new $C_{\mathrm{i}}$ value according to the given $g_{\mathrm{sc}}$ value and the relationship between $A_{\mathrm{n}}$ and $C_{\mathrm{i}}$. If the difference between this $C_{\mathrm{i}}$ value and the previously given $C_{\mathrm{i}}$ value is less than a certain smaller critical value (such as 0.01 ), the model goes to the simulation of stomatal conductance, otherwise repeat the photosynthesis model, until it meets the requirements;

5. Substituting the modeled $A_{\mathrm{n}}$ and $C_{\mathrm{s}}$ into the stomatal conductance model to obtain a new $g_{\mathrm{sc}}$, if the difference between the value and the previously given $g_{\text {sc }}$ is less than a certain smaller critical value (such as 0.0001), the model goes to the next period, otherwise repeat Eqs. 2-5, until it meets the requirements.

\section{Evaluation Phase}

Model calculated $F_{\mathrm{c}}$ and $L E$ values were compared to the direct observed values using standard statistics and regression analysis. In this paper, we used Mean absolute error (MAE) and root mean squared error (RMSE) as aggregate indicators of model performance. They were computed as:

$\mathrm{MAE}=\frac{1}{n} \sum_{i=1}^{n}\left|X_{\mathrm{mod}, i}-X_{\mathrm{obs}, i}\right|$

$\mathrm{RMSE}=\sqrt{\frac{1}{n} \sum_{i=1}^{n}\left(X_{\mathrm{mod}, i}-X_{\mathrm{obs}, i}\right)^{2}}$

where $X_{\text {mod,i }}$ and $X_{\text {obs,i }}$ are the modeled and observed $F_{\mathrm{c}}$ and $L E$ values, respectively for each day $i$ (or $30 \mathrm{~min}$ ) and $n$ is the sample number.

\section{Simulation Processes}

Using the above mentioned multilayered model to simulate the canopy net photosynthesis and evapotranspiration rate from May to August (2010-2011) in Horqin meadow grassland. The time step is $30 \mathrm{~min}$. Using $30 \mathrm{~min}$ meteorological data from the meteorological observation tower in Horqin meadow grassland test site as the environmental input variable to calculate the photosynthesis within canopy in the corresponding time, thereby a series of daily and season changes in photosynthesis obtained. Furthermore, the model sensitivity to parameters and variables were analyzed.

Detailed description is as follows:

1. Input of environmental factors Environmental factor data collected every half hour from May 1st to August 30th (2010-2011) (temperature $T_{\mathrm{a}}$, water vapor pressure $e_{\mathrm{a}}$, solar radiation $S_{0}$, photosynthetically active radiation $P A R$, wind speed $u_{0}$, atmospheric pressure $P$, atmosphere The $\mathrm{CO}_{2}$ concentration in the $C_{\mathrm{a}}$ ) input into the model.

2. Simulation of radiation absorption Based on the canopy stratification and the corresponding cumulative leaf area index $\xi_{t}$, the solar radiation absorbed by the illuminated and shaded leaves in each layer and the photosynthetically active radiation are calculated.

3. Simulation of the foliar process Including photosynthesis model, energy balance equation, stomatal conductance model. Numerical solution method was used in the process as that in the calibration phase described.

4. Simulation of canopy scale $\mathrm{The} A_{\mathrm{sl}}, A_{\mathrm{sh}}, L E_{\mathrm{sl}}$, and $L E_{\mathrm{sh}}$ of the shaded leaves obtained by the foliar process simulation are substituted into the net photosynthesis calculation formula to obtain the $A_{\mathrm{n}}$ and $L E$ values of a certain layer at that time, and then return to step 2 . The simulation of the other layer of the canopy, the final layers are summed, and the total photosynthesis rate $A_{\mathrm{c}}$ and evapotranspiration rate $L E_{\mathrm{c}}$ of the entire canopy at that time are obtained.

5. Daily values of carbon and water fluxes were calculated to analyze the seasonal variation.

6. Model sensitivity analyses when the physiological parameters, environmental factors and vegetation parameters changed.

\section{Model Validation}

The canopy $\mathrm{CO}_{2}$ and $\mathrm{H}_{2} \mathrm{O}$ fluxes $\left(A_{\mathrm{c}}\right.$ and $\left.L E_{\mathrm{c}}\right)$ used for validation were eddy covariance measurements $\left(A_{\text {eco }}\right.$ and $\left.L E_{\text {eco }}\right)$ minus the soil $\mathrm{CO}_{2}\left(R_{\text {soil }}\right)$ and $\mathrm{H}_{2} \mathrm{O}$ fluxes $\left(L E_{\text {soil }}\right)$, respectively.

$A_{\text {eco }}=A_{c}+R_{\text {soil }}$

$L E_{\text {eco }}=L E_{c}+L E_{\text {soil }}$

$R_{\text {soil }}$ is estimated with consideration of the soil temperature at $0.05 \mathrm{~m}$ soil depth $\left(T_{\mathrm{s}}\right)$ using an exponential equation:

$R_{\text {soil }}=a 3 \cdot \exp \left(b 3 \cdot T_{s}\right)$

According to Chen et al. (2011), the value of $a 3$ is 0.678 and that of $b 3$ is 0.106 . 


\section{Results and Discussion}

\section{Verification of the Multilayered Model}

Observation data recorded from May to August, 2010 and 2011 in the Korqin meadow were selected to validate the simulation of carbon and water fluxes by the multilayered model. The simulated 30-min values for carbon flux $F_{\mathrm{c}}$ and water flux $L E$ and the observed ones showed good correspondence (Fig. 2). The linear regression line was close to the 1:1 line. The slope, intercept, correlation coefficient, sample number, mean absolute error (MAE), and root mean square error (RMSE) are shown in Table 2. The multilayered model underestimated $F_{\mathrm{c}}$ and $L E$ by about $0.6 \%$ and $5.0 \%$, respectively.

The simulation results of the model were not uniform in different days, months, and years. For the different years, $F_{\mathrm{c}}$ was overestimated by $8.6 \%$ and underestimated by $4.9 \%$,
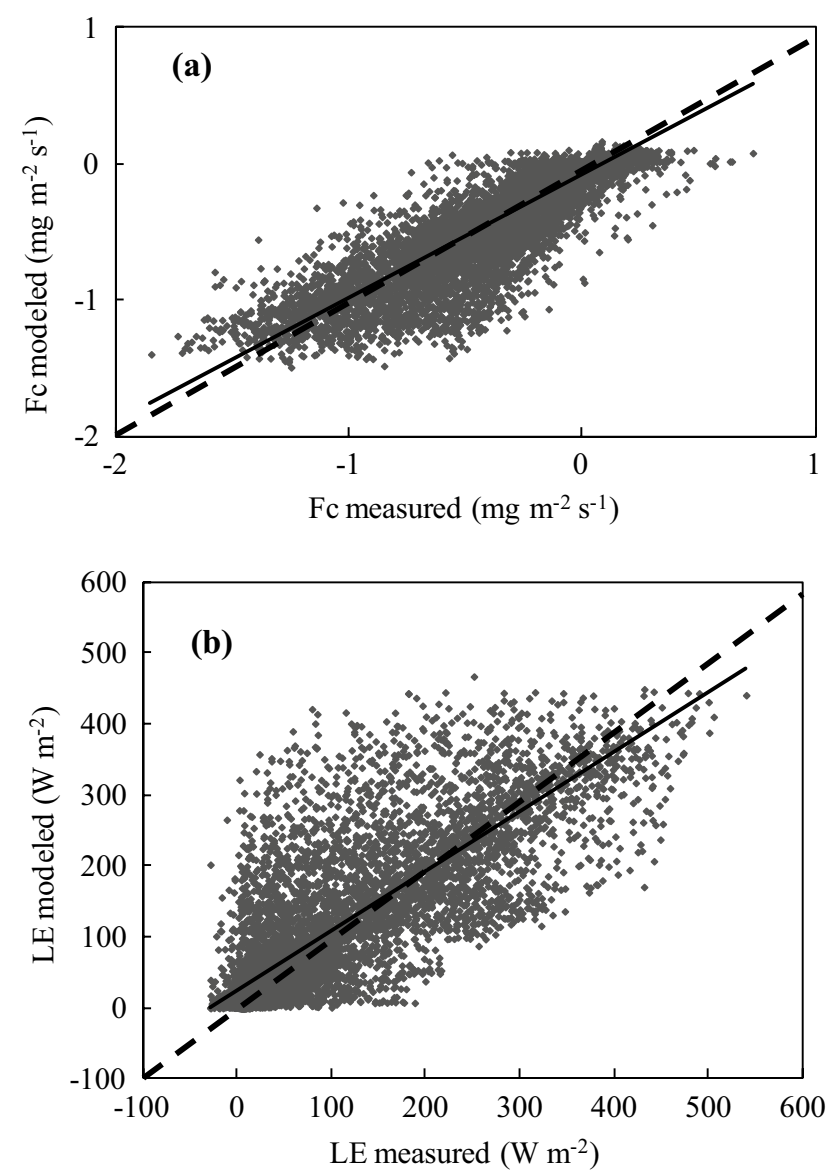

Fig. 2 Comparison of modeled (Y-axis) against measured (X-axis) 30 min carbon and water flux a carbon flux $\left(F_{\mathrm{c}}\right)$, and $\mathbf{b}$ water flux ( $L E$ ) during May to August, 2010-2011. The solid lines were the best fit linear regressions $(y=a x+b)$, and the dashed lines represented $1: 1$ relation whereas $L E$ was underestimated by $3.1 \%$ and $6.6 \%$, in 2010 and 2011, respectively. For different months, $F_{\mathrm{c}}$ was underestimated by $18.8 \%$ and overestimated by $1.9 \%$, and $L E$ was underestimated by $34.3 \%$ and $1.8 \%$, early in the growing season (May) and during the growing season (June to August), respectively. For daytime (photosynthetically active radiation PAR $\left.>5 \mu \mathrm{mol} \mathrm{m}^{-2} \mathrm{~s}^{-1}\right), F_{\mathrm{c}}$ and $L E$ were overestimated by $2.0 \%$ and underestimated by $5.8 \%$, respectively.

\section{Simulation of Diurnal Variation of Carbon and Water Fluxes}

Simulation of diurnal variation of carbon and water fluxes was analyzed using observation data for three consecutive days per month from May to August in 2011 (Fig. 3). The $\mathrm{CO}_{2}$ and $\mathrm{H}_{2} \mathrm{O}$ fluxes showed distinct diurnal cycles, represented by bell-shaped curves, with low and steady values at night and unimodal distribution of values during the day. The carbon flux was positive at night and negative in the daytime. The ecosystem changed from $\mathrm{CO}_{2}$ release to absorption after sunrise, and reverted from $\mathrm{CO}_{2}$ absorption to release before sunset. The maximum net absorption of $\mathrm{CO}_{2}$ was attained at about 11:30. The water vapor flux was small at night, increased after sunrise, and gradually decreased after sunset. The maximum water vapor flux was attained at around 12:30. Trends for the simulated and observed 30-min values of $F_{\mathrm{c}}$ and $L E$ were essentially identical. Correspondence between the simulated and observed values was superior during the day than at night.

\section{Simulation of Seasonal Variation of Carbon and Water Fluxes}

The seasonal variation (Fig. 4) showed that the simulation values for $F_{\mathrm{c}}$ were consistent with the observed values. The total $F_{\mathrm{c}}$ early in the growing season (May) was low, whereas in the growing season (June-August) was much higher. These results are associated with the LAI, leaf physiological activity, and environmental factors such as temperature and radiation. Compared with the observed eddy-covariance values, the simulated values for $F_{\mathrm{c}}$ were higher early in the growing season (May) because leaf physiological activities are poor and the chlorophyll content is lower. The simulation of $L E$ was not reliable, the simulated value was low early in the growing season (May) because the LAI is lower in May and soil evaporation is a large component of $L E$.

\section{Sensitivity of Multilayered Model to Parameters and Variables}

We analyzed sensitivity of multilayered model to the physiological parameters (the parameter $a_{1}$, the empirical coefficient of stomatal response to saturated vapor pressure 
Table 2 Linear regressions between measured and modeled 30 min carbon and water fluxes and model error estimation

\begin{tabular}{|c|c|c|c|c|c|c|c|}
\hline Flux & Process & $\mathrm{a}$ & $\mathrm{b}$ & $\mathrm{R}^{2}$ & MAE & RMSE & $\mathrm{n}$ \\
\hline \multirow[t]{9}{*}{ Carbon $F_{\mathrm{c}} \mathrm{mg} \mathrm{m}^{-2} \mathrm{~s}^{-1}$} & Total & 0.911 & -0.082 & 0.801 & 0.128 & 0.194 & 8799 \\
\hline & Year & & & & & & \\
\hline & 2010 & 0.986 & -0.083 & 0.818 & 0.133 & 0.199 & 3834 \\
\hline & 2011 & 0.861 & -0.080 & 0.797 & 0.119 & 0.190 & 4965 \\
\hline & Month & & & & & & \\
\hline & May & 0.732 & -0.034 & 0.675 & 0.073 & 0.109 & 2702 \\
\hline & June-August & 0.889 & -0.120 & 0.796 & 0.159 & 0.224 & 6097 \\
\hline & Day & & & & & & \\
\hline & Daytime & 0.84 & -0.141 & 0.688 & 0.175 & 0.235 & 5696 \\
\hline \multirow[t]{9}{*}{ Water $L E \mathrm{~W} \mathrm{~m}^{-2}$} & Total & 0.842 & 23.48 & 0.672 & 39.68 & 65.26 & 8548 \\
\hline & Year & & & & & & \\
\hline & 2010 & 0.836 & 29.81 & 0.624 & 46.37 & 75.06 & 3602 \\
\hline & 2011 & 0.843 & 19.17 & 0.716 & 34.81 & 57.08 & 4946 \\
\hline & Month & & & & & & \\
\hline & May & 0.524 & 18.02 & 0.368 & 30.17 & 51.02 & 2458 \\
\hline & June-August & 0.839 & 33.01 & 0.683 & 43.52 & 70.20 & 6090 \\
\hline & Day & & & & & & \\
\hline & Daytime & 0.753 & 44.59 & 0.565 & 54.72 & 79.48 & 5681 \\
\hline
\end{tabular}

$\mathrm{a}, \mathrm{b}$ and $\mathrm{R}^{2}$ is the slope, intercept and coefficient of determination, respectively in the regression equation, $\mathrm{n}$ the sample number

$M A E$ mean absolute error, $R M S E$ root mean squared error difference $\mathrm{Vpd}_{\mathrm{s} 0}$, the minimum stomatal conductance of $\mathrm{CO}_{2}$ at the light compensation point $g_{\mathrm{sc} 0}$, the leaf nitrogen content distribution coefficient $k_{\mathrm{n}}$, and maximum Rubisco catalytic activity $V_{\text {cmax }}$ ), environmental factors (PAR, vapor pressure deficit VPD, wind speed $u_{0}$, soil water content $\theta_{\text {sm }}$, air temperature $T_{\mathrm{a}}$, atmospheric $\mathrm{CO}_{2}$ concentration $C_{\mathrm{a}}$ ), and vegetation parameters (leaf area index LAI). The cumulative canopy carbon and water fluxes from May to August with changes in the parameters were shown in Fig. 5. The amplitude of canopy cumulative $F_{\mathrm{c}}$ and $L E$ after changes of parameters is shown in Table 3. The cumulative canopy $F_{\mathrm{c}}$ and $L E$ declined with decrease in the value of $a_{1}$, $\mathrm{Vpd}_{\mathrm{s} 0}, g_{\mathrm{sc} 0}$, PAR and vice versa. But they increased when $k_{\mathrm{n}}, V_{\text {cmax }}$ decreased and vice versa. The cumulative $F_{\mathrm{c}}$ and $L E$ decreased concomitant with decrease in temperature. With progressive increase in temperature, the cumulative $F_{\mathrm{c}}$ and $L E$ initially increased but thereafter decreased. VPD had little effect on $F_{\mathrm{c}}$, but had a greater influence on $L E$. With a reduction in VPD, cumulative $F_{\mathrm{c}}$ increased and $L E$ decreased, and vice versa. The effect of $u_{0}$ on cumulative $F_{\mathrm{c}}$ and $L E$ was small; when the wind speed increased by $10 \%$, the influence on simulated values of $F_{\mathrm{c}}$ and $L E$ was less than $0.1 \%$. $C_{\mathrm{a}}$ had a greater effect on $F_{\mathrm{c}}$ and less impact on $L E$. The effect of $\theta_{\mathrm{sm}}$ on $F_{\mathrm{c}}$ and $L E$ was small.

$\mathrm{CO}_{2}$ flux was most sensitive to $k_{\mathrm{n}}$ and $V_{\text {cmax }}$, whereas water vapor flux was most sensitive to other physiological parameters. The sensitivity of $F_{\mathrm{c}}$ to individual environmental factors was ranked as $C_{\mathrm{a}}>T_{\mathrm{a}}>\mathrm{PAR}>\theta_{\mathrm{sm}}>\mathrm{VPD}>u_{0}$, whereas the rank order of sensitivity of $L E$ to environmental factors was $T_{\mathrm{a}}>\mathrm{VPD}>\theta_{\mathrm{sm}}>\mathrm{PAR}>C_{\mathrm{a}}>u_{0}$. The response of $L E$ to vegetation parameters was greater than that of $F_{\mathrm{c}}$. Overall, the multilayered model could be used to simulate the multi-species meadow canopy productivity under climate change.

\section{Discussion}

\section{Common Issues When Simulating Carbon and Water Flux}

The multilayered model underestimated $F_{\mathrm{c}}$ and $L E$ by about $0.6 \%$ and $5.0 \%$, respectively at meadow site. Similar phenomenon found by some scholars (Shi et al. 2010; Chang et al. 2018; Reed et al. 2018). Underestimations of $F_{\mathrm{c}}$ at meadow site are expected to have resulted from soil respiration which was simply to the exponential relationship of soil temperature. Underestimations of $L E$ are expected to have resulted from canopy evaporation, transpiration, and soil evaporation estimation errors. Systematic measurements on each component of evapotranspiration are essential for the further evaluation and calibration of latent heat flux estimations for vegetated surfaces (Zhang et al. 2016).

The model performed well during the day and in the growing season, but poorly at night and early in the growing season. The reason for this difference is that $F_{\mathrm{c}}$ during 

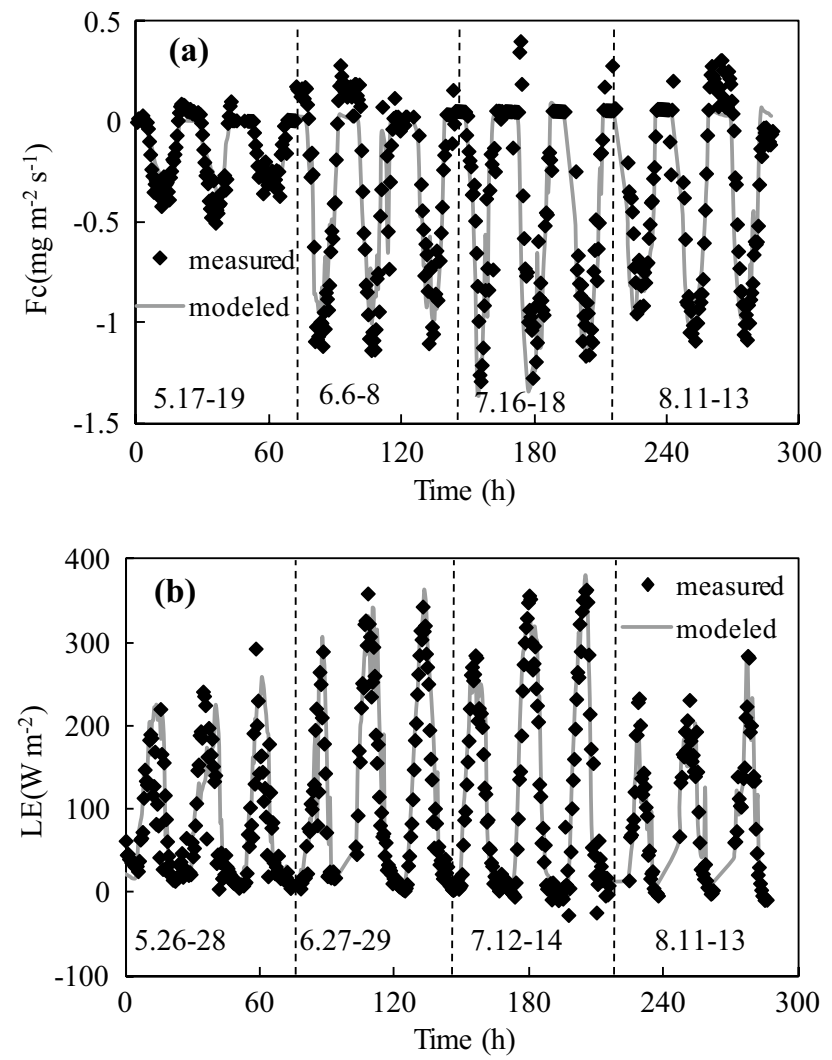

Fig. 3 Comparison of diurnal variation of modeled (line) and measured (dot) canopy carbon and water flux during growing season (May-August, 2011) a $F_{\mathrm{c}}$, b LE. 3 days' data in each month were randomly selected

the day mainly includes canopy photosynthesis, and vegetation and soil respiration, and canopy photosynthesis activity is much greater than respiration activity. The simulated values for the canopy were similar to the observed values. The $F_{\mathrm{c}}$ at night is mainly from vegetation and soil respiration. Soil respiration is affected by soil moisture content, nutrient concentrations, and soil microbe activities (Huang et al. 2015; Drollinger et al. 2017). The current model does not consider the latter two factors. The low wind speed led to a lower air temperature at the soil surface than at the reference height, resulting in an atmospheric inversion layer, but the model does not account for this temperature difference.

The reason for poor estimation early in the growing season is that physiological and ecological processes in the canopy leaves were mainly considered, but LAI and $V_{\text {cmax }}$ at the beginning and end of the growing season each differ substantially, and hence resulted in the deviations in the simulations. Mover, leaf chlorophyll concentration was not measured owing to the limitation of the installed instruments, therefore the impact of chlorophyll content is ignored and the $F_{\mathrm{c}}$ value is small in May. Thus, the percentage error
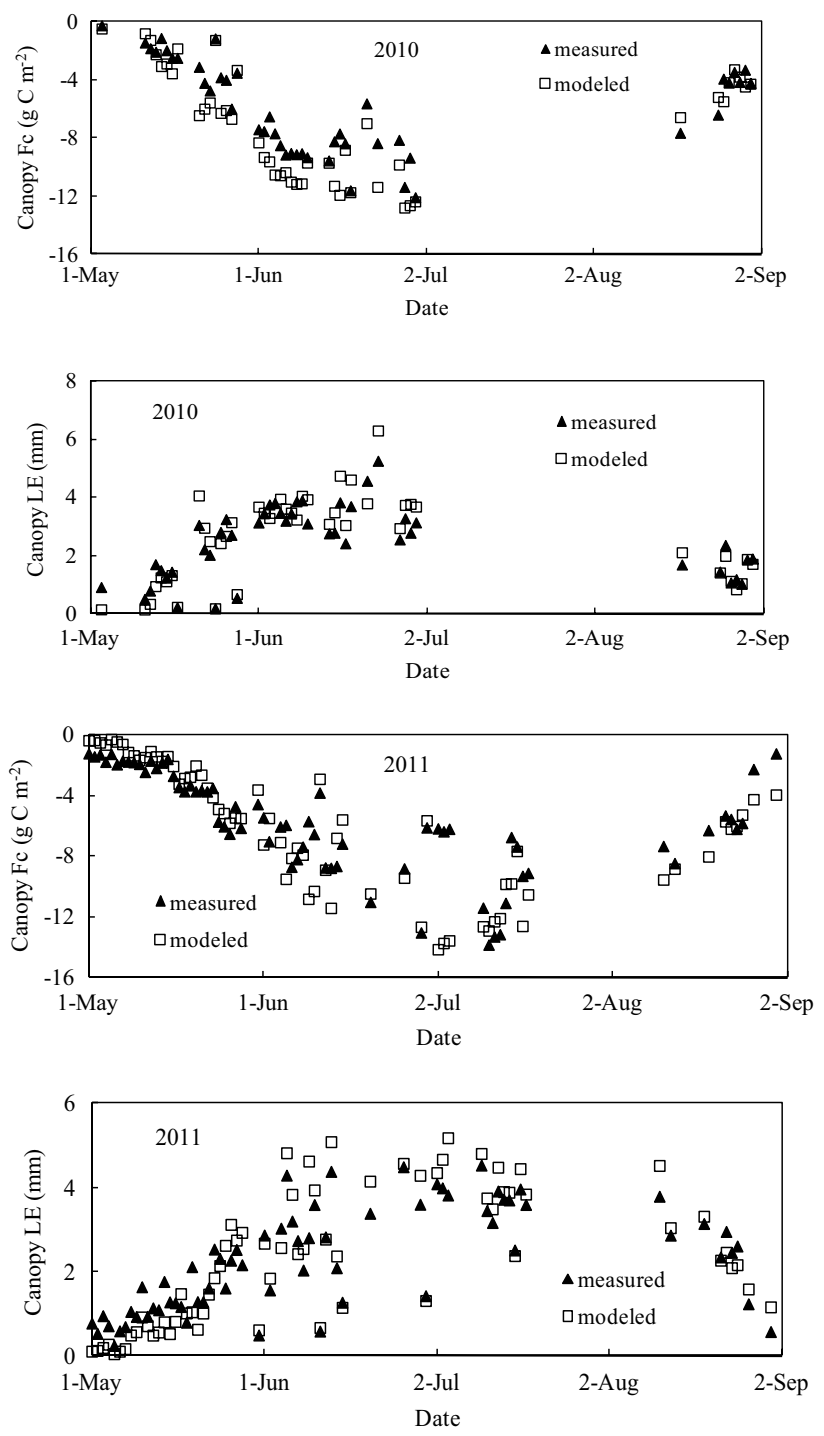

Fig. 4 Seasonal variation of modeled and measured canopy daily carbon and water fluxes for May to August, 2010-2011

is relatively large. The reason for the dispersion on $L E$ simulated data is that soil evaporation is a large component of $L E$. It is not only related to LAI, but also associated with solar radiation, temperature, the saturated vapor pressure difference, wind speed, and other environmental factors. In addition, relatively few leaves have developed in the vegetation in May, and thus the model mainly simulated canopy evaporation and neglected that of the stem. Overall, the multilayered model could be used to simulate the multi-species meadow canopy productivity.

\section{Values of the Parameters of the Model}

Simulation of $\mathrm{CO}_{2}$ and $\mathrm{H}_{2} \mathrm{O}$ fluxes affected by values of key input parameters and variables of the model (Liu et al. 
Fig. 5 Sensitivity analysis of the multi-layered model for the parameters (take 2011 for example). $\mathrm{X}$-axis was the date, and $\mathrm{Y}$-axis was the canopy cumulative of carbon and water fluxes before and after changes of parameters. The black solid lines were the initial values
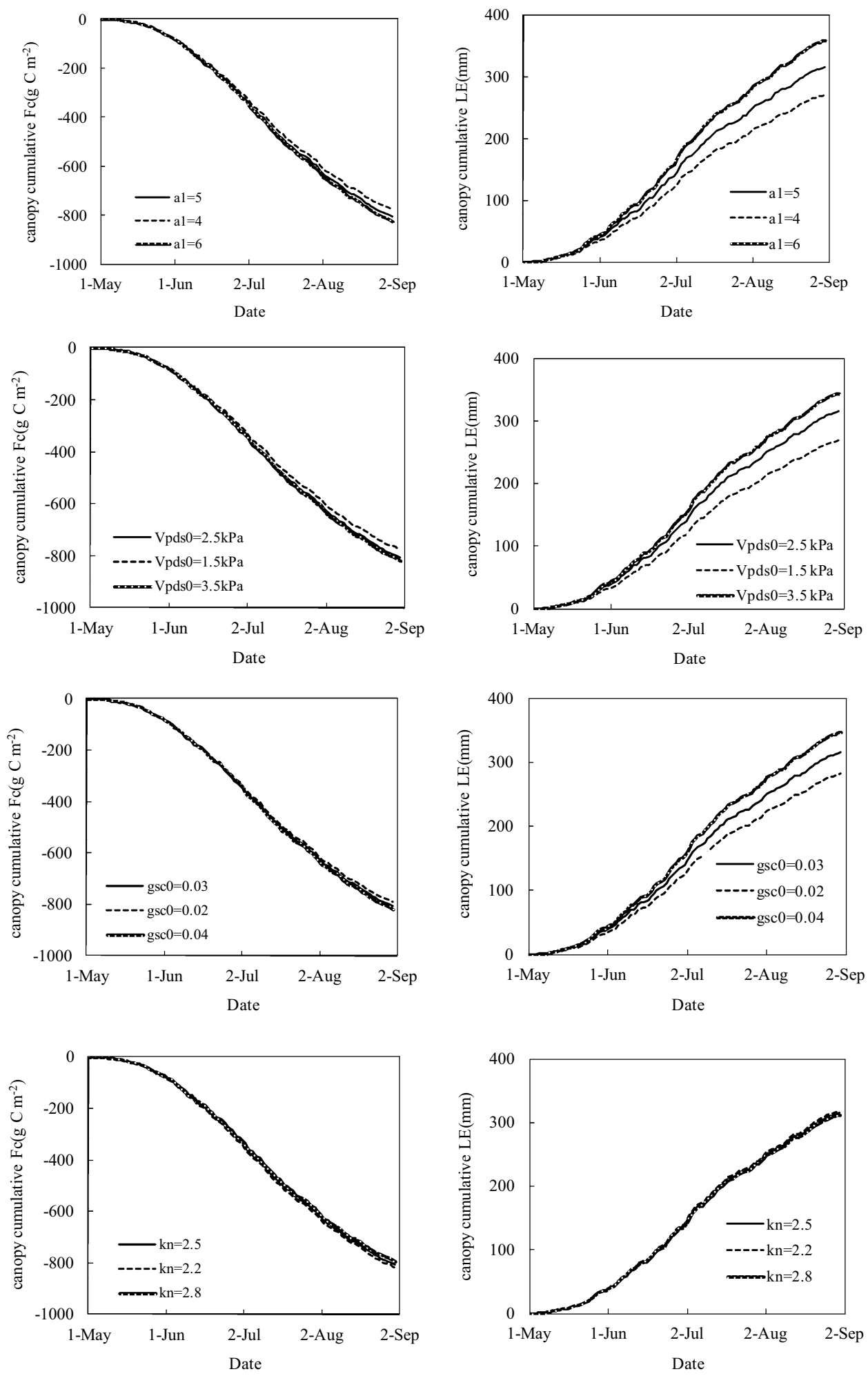

2015). The parameter $a_{1}$ is associated with the intercellular $\mathrm{CO}_{2}$ concentration at light saturation. Leuning et al. (1995) determined in the multilayered model that $a_{1}$ ranged in value from 4 to 9 depending on the leaf nitrogen content. Wang and Leuning (1998) reported the $a_{1}$ value to be 11 in a two-leaf model. The empirical coefficient $\mathrm{Vpd}_{\mathrm{s} 0}$ reflects the sensitivity of leaf stomatal conductance to the surface saturated vapor pressure difference $\mathrm{Vpd}_{\mathrm{s}}$. Leuning et al. (1995) determined the $\mathrm{Vpd}_{\mathrm{s} 0}$ value to be $1.5-3.5 \mathrm{kPa}$. Harley et al. (1992) reported the value of $g_{\text {sc } 0}$ to be $0.03-0.05 \mathrm{~mol}$ 
Fig. 5 (continued)
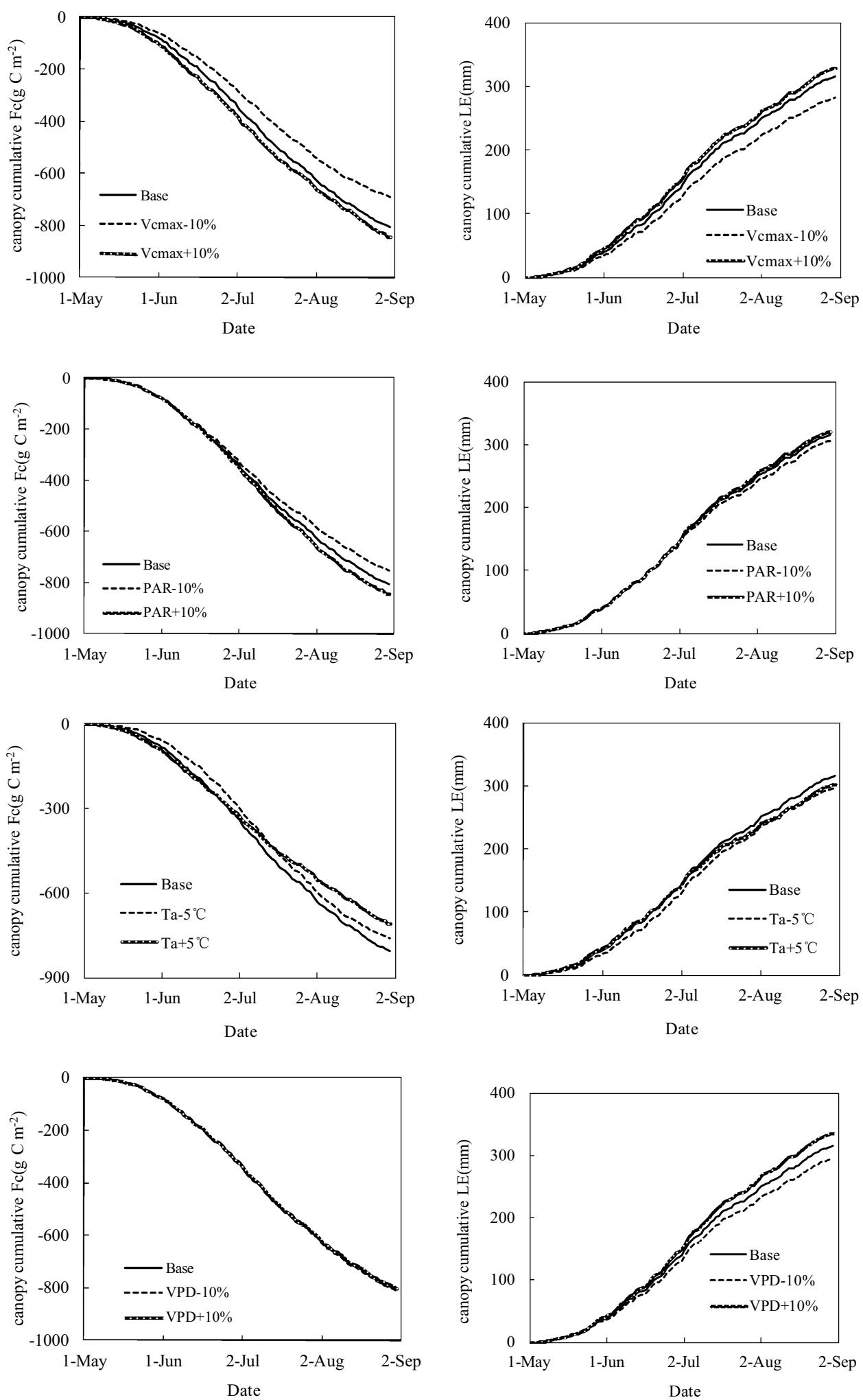

$\mathrm{CO}_{2} \mathrm{~m}^{-2} \mathrm{~s}^{-1}$. The parameter $k_{\mathrm{n}}$ reflects the degree of attenuation of leaf nitrogen in the canopy. The majority of leaf nitrogen is a constituent of photosynthesis-related enzymes.
The value of $k_{\mathrm{n}}$ varies among studies, and between sparse and dense canopies, with reported values ranging from 0.08 to 2.8 (Schieving et al. 1992; Archontoulis et al. 2011). 
Fig. 5 (continued)
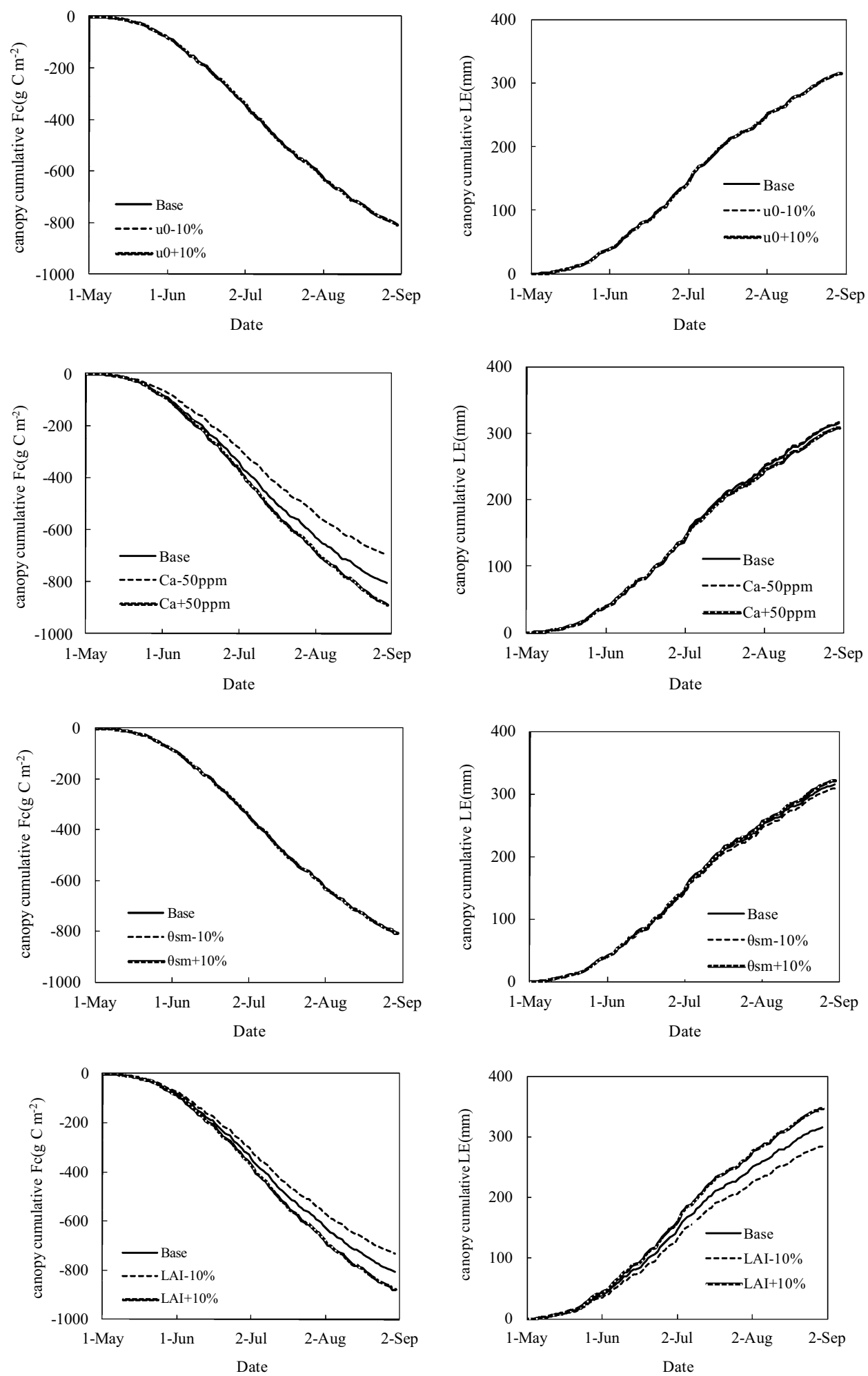

Leuning et al. (1995) showed that change in $k_{\mathrm{n}}(0.0-1.2)$ had little impact on the $\mathrm{CO}_{2}$ assimilation rate under any light condition if the leaf nitrogen content was high. However, if the leaf nitrogen content was low, the total daily $\mathrm{CO}_{2}$ assimilation increased by about $10-16 \%$ if $k_{\mathrm{n}}$ increased from 0.0 to 1.2 . The maximum Rubisco catalytic response rate $V_{\text {cmax }}$ varies from 23.4 to $99.6 \mu \mathrm{mol} \mathrm{m}^{-2} \mathrm{~s}^{-1}$ among species and observation seasons (Chen et al. 2014). In this paper, we 
Table 3 Amplitude of canopy cumulative carbon and water fluxes after changes of parameters

\begin{tabular}{|c|c|c|c|c|}
\hline Parameters & $\begin{array}{l}\text { Parameters (initial } \\
\text { value) }\end{array}$ & Amplitude (analysis value) & Amplitude of $F_{c}$ & Amplitude of $L E$ \\
\hline \multirow[t]{10}{*}{ Physiological parameters } & \multirow[t]{2}{*}{$a 1(5)$} & 4 & $-3.5 \%$ & $-14.2 \%$ \\
\hline & & 6 & $+2.4 \%$ & $+13.8 \%$ \\
\hline & \multirow[t]{2}{*}{$v_{p d s 0}(2.5)$} & 1.5 & $-3.9 \%$ & $-14.9 \%$ \\
\hline & & 3.5 & $+1.6 \%$ & $+8.9 \%$ \\
\hline & \multirow[t]{2}{*}{$g_{s c 0}(0.03)$} & 0.02 & $-1.9 \%$ & $-10.9 \%$ \\
\hline & & 0.04 & $+1.5 \%$ & $+10.4 \%$ \\
\hline & \multirow[t]{2}{*}{$k_{\mathrm{n}}(2.5)$} & 2.2 & $+1.6 \%$ & $+1.1 \%$ \\
\hline & & 2.8 & $-1.6 \%$ & $-1.2 \%$ \\
\hline & \multirow[t]{2}{*}{$V_{c \max }$} & $+10 \%$ & $+6.1 \%$ & $+5.1 \%$ \\
\hline & & $-10 \%$ & $-14.8 \%$ & $-10.8 \%$ \\
\hline \multirow[t]{12}{*}{ Environmental factors } & \multirow[t]{2}{*}{$P A R$} & $+10 \%$ & $+4.5 \%$ & $+1.3 \%$ \\
\hline & & $-10 \%$ & $-6.0 \%$ & $-2.6 \%$ \\
\hline & \multirow[t]{2}{*}{$T_{\mathrm{a}}$} & $+5^{\circ} \mathrm{C}$ & $-10.7 \%$ & $-3.3 \%$ \\
\hline & & $-5^{\circ} \mathrm{C}$ & $-6.4 \%$ & $-6.6 \%$ \\
\hline & \multirow[t]{2}{*}{$V P D$} & $+10 \%$ & $-0.55 \%$ & $+6.3 \%$ \\
\hline & & $-10 \%$ & $+0.55 \%$ & $-6.5 \%$ \\
\hline & \multirow[t]{2}{*}{$u_{0}$} & $+10 \%$ & $+0.07 \%$ & $+0.09 \%$ \\
\hline & & $-10 \%$ & $-0.06 \%$ & $-0.10 \%$ \\
\hline & \multirow[t]{2}{*}{$C_{\mathrm{a}}$} & $+50 \mu \mathrm{mol} \mathrm{mol}-1$ & $+11.0 \%$ & $-1.69 \%$ \\
\hline & & $-50 \mu \mathrm{mol} \mathrm{mol}{ }^{-1}$ & $-13.2 \%$ & $+0.38 \%$ \\
\hline & \multirow[t]{2}{*}{$\theta_{\mathrm{sm}}$} & $+10 \%$ & $+0.21 \%$ & $+1.89 \%$ \\
\hline & & $-10 \%$ & $-0.26 \%$ & $-1.97 \%$ \\
\hline \multirow[t]{2}{*}{ Vegetation characteristic parameter } & \multirow[t]{2}{*}{$L A I$} & $+10 \%$ & $+8.9 \%$ & $+9.8 \%$ \\
\hline & & $-10 \%$ & $-9.1 \%$ & $-9.9 \%$ \\
\hline
\end{tabular}

evaluated a1 as $5, \mathrm{Vpd}_{\mathrm{s} 0}$ as $1.5 \mathrm{kPa}, g_{\mathrm{sc} 0}$ as $0.03 \mathrm{~mol} \mathrm{~m}^{-2} \mathrm{~s}^{-1}$, $k_{\mathrm{n}}$ as 2.5, and $V_{\mathrm{cmax}}$ as 23.4-99.6 $\mu$ mol m $\mathrm{m}^{-2} \mathrm{~s}^{-1}$ separately among five species. We further analyzed the sensitivity of multilayered model to parameters and variables, the results indicated that $F_{\mathrm{c}}$ was more sensitive to $k_{\mathrm{n}}$ and $V_{\mathrm{cmax}}$, whereas $L E$ showed greater sensitivity to other physiological parameters $\left(a_{1}, \mathrm{~V}_{\mathrm{pds} 0}\right.$ and $\left.g_{\mathrm{sc} 0}\right)$.

Acknowledgements Supported by National Natural Science Foundation of China (41705094; 41975149), Liaoning Provincial Key R\&D Guidance Plan (2019JH8/10200022), Liaoning Meteorological Administration Special Foundation for Doctors (D201505), The 13th Five-Year National Key R\&D Program "Food High-yield and Efficiency-Innovative Technology Innovation" (2018YFD0200809), Science and Technology Department Key Program Guidance Program (2017210001), LiaoNing Revitalization Talents Program (XLYC1807262). There is no conflict of interest in the manuscript.

Open Access This article is distributed under the terms of the Creative Commons Attribution 4.0 International License (http://creat ivecommons.org/licenses/by/4.0/), which permits unrestricted use, distribution, and reproduction in any medium, provided you give appropriate credit to the original author(s) and the source, provide a link to the Creative Commons license, and indicate if changes were made.

\section{References}

Amthor, J. S. (1994). Scaling $\mathrm{CO}_{2}$-photosynthesis relationships from the leaf to canopy. Photosynthesis Research, 39, 321-350.

Aphalo, P. J., \& Jarvis, P. G. (1993). The boundary layer and the apparent responses of stomatal conductance to wind speed and to the mole fractions of $\mathrm{CO}_{2}$ and water vapour in the air. Plant Cell and Environment, 16, 771-783.

Archontoulis, S. V., Vos, J., Yin, X., Bastiaans, L., Danalatos, N. G., \& Struik, P. C. (2011). Temporal dynamics of light and nitrogen vertical distributions in canopies of sunflower, kenaf and cynara. Field Crops Research, 122, 186-198.

Chang, K. Y., Tha, P. U. K., \& Chen, S. H. (2018). The importance of carbon-nitrogen biogeochemistry on water vapor and carbon fluxes as elucidated by a multiple canopy layer higher order closure land surface model. Agricultural and Forest Meteorology, 259, 60-74.

Chen, N. N., Guan, D. X., Jin, C. J., Yuan, F. H., \& Yang, H. (2011). Characteristics of soil respiration on horqin meadow. Chinese Journal of Grassland, 33(5), 82-87.

Chen, N. N., Wang, A. Z., Jin, C. J., Yuan, F. H., Wu, J. B., Guan, D. X., et al. (2014). Variability of photosynthetic parameters of five species in a temperate meadow in eastern Inner Mongolia. Journal of Food Agriculture and Environment, 12(2), 939-942.

Drollinger, S., Müller, M., Kobl, T., Schwab, N., Böhner, J., Schickhoff, U., et al. (2017). Decreasing nutrient concentrations in soils and trees with increasing elevation across a treelineecotone in rolwaling himal, Nepal. Journal of Mountain Science, 14(5), 843-858. 
Farquhar, G. D., von Caemmerer, S., \& Berry, J. A. (1980). A biochemical model of photosynthetic $\mathrm{CO}_{2}$ assimilation in leaves of $\mathrm{C}_{3}$ species. Planta, 149, 78-90.

Fell, M., Barber, J., Lichstein, J. W., \& Ogle, K. (2018). Multidimensional trait space informed by a mechanistic model of tree growth and carbon allocation. Ecosphere, 9(1), e02060.

Goudriaan, J., \& van Laar, H. H. (1994). Modelling potential crop growth processes. Dordrecht: Kluwer Academic Publishers.

Han, G. D., Hao, X. Y., Zhao, M. L., Wang, M. J., Ellert, B. H., \& Walter, W. (2008). Effect of grazing intensity on carbon and nitrogen in soil and vegetation in a meadow steppe in Inner Mongolia. Agriculture Ecosystems Environment, 125, 21-32.

Harley, P. C., Thomas, R. B., Reynolds, J. F., \& Strain, B. R. (1992). Modeling photosynthesis of cotton grown in elevated $\mathrm{CO}_{2}$. Plant Cell and Environment, 15, 271-282.

He, L., Li, J., Harahap, M., \& Yu, Q. (2017). Scale-specific controller of carbon and water exchanges over wheat field identified by ensemble empirical mode decomposition. International Journal of Plant Production. https://doi.org/10.1007/s42106-017-0005-8.

Huang, C. W., Domec, J. C., Ward, E. J., Duman, T., Manoli, G., Parolari, A. J., et al. (2016). The effect of plant water storage on water fluxes within the coupled soil-plant system. New Phytologist, 213(3), 1093-1106.

Huang, G., Li, Y., \& Su, Y. G. (2015). Effects of increasing precipitation on soil microbial community composition and soil respiration in a temperate desert, northwestern China. Soil Biology Biochemistry, 83, 52-56.

IPCC. (2001). Climate change 2001: the scientific base-contribution of working group I to the IPCC third assessment report. New York: Cambridge University Press.

Kucharik, C. J., Barford, C. C., Maayar, M. El., Wofsy, S. C., Monson, R. K., \& Baldocchi, D. D. (2006). A multiyear evaluation of a dynamic global vegetation model at three AmeriFlux forest sites: vegetation structure, phenology, soil temperature, and $\mathrm{CO}_{2}$ and $\mathrm{H}_{2} \mathrm{O}$ vapor exchange. Ecological Modelling, 196, 1-31.

Leuning, R. (1995). A critical appraisal of a combined stomatal-photosynthesis model for $\mathrm{C}_{3}$ plants. Plant Cell and Environment, 18, 339-357.

Leuning, R., Dunin, F. X., \& Wang, Y. P. (1998). A two-leaf model for canopy conductance, photosynthesis and partitioning of available energy: II. Comparison with measurements. Agricultural and Forest Meteorology, 91, 113-125.

Leuning, R., Kelliher, F. M., De Pury, D. G. G., \& Schulze, E. D. (1995). Leaf nitrogen, photosynthesis, conductance and transpiration: scaling from leaves to canopies. Plant Cell and Environment, 18(10), 1183-1200.

Liao, G., \& Jia, Y. (1996). Grassland resource of China. Beijing: Chinese Science and Technology Publisher.

Liu, M., He, H. L., Ren, X. L., Sun, X. M., Yu, G. R., Han, S. J., et al. (2015). The effects of constraining variables on parameter optimization in carbon and water flux modeling over different forest ecosystems. Ecological Modelling, 303, 30-41.

McMurtrie, R. E., Leuning, R., Thompson, W. A., \& Wheeler, A. M. (1992). A model of canopy photosynthesis and water use incorporating a mechanistic formulation of leaf $\mathrm{CO}_{2}$ exchange. Forest Ecology and Management, 2(1/4), 261-278.
Qu, J., \& Zhao, D. (2016). Stabilising the cohesive soil with palm fibre sheath strip. Road Materials and Pavement Design, 17(1), 87-103.

Reed, D. E., Ewers, B. E., Pendall, E., Naithani, K. J., Kwon, H., \& Kelly, R. D. (2018). Biophysical factors and canopy coupling control ecosystem water and carbon fluxes of semiarid sagebrush ecosystems. Rangeland Ecology Management, 71, 309-317.

Schieving, F., Pons, T. L., Werger, M. J. A., \& Hirose, T. (1992). The vertical distribution of nitrogen and photosynthetic activity at different plant densities in Carex acutiformis. Plant and Soil, 14, $9-11$.

Sellers, P. J., Berry, J. A., Collatz, G. J., Field, C. B., \& Hall, F. G. (1992). Canopy reflectance, photosynthesis, and transpiration. III. A reanalysis using improved leaf models and a new canopy integration scheme. Remote Sensing of Environment, 42(3), 187-216.

Sellers, P. J., Randall, D. A., Collatz, G. J., Berry, J. A., Field, C. B., Dazlich, D. A., et al. (1996). A revised land surface parameterization (SiB2) for atmospheric GCMs Part I: model formulation. Journal of Climate, 9(4), 679-705.

Shen, X., Zhang, M. Z., \& Qi, X. B. (2011). Comparison of regional forest carbon estimation methods based on regression and stochastic simulation. Scientia Silvae Sinicae, 47(6), 1-8.

Shi, T. T., Guan, D. X., Wang, A. Z., Wu, J. B., Yuan, F. H., Jin, C. J., et al. (2010). Modeling canopy $\mathrm{CO}_{2}$ and $\mathrm{H}_{2} \mathrm{O}$ exchange of a temperate mixed forest. Journal of Geophysical Research, 115, D17117.

Stewart, J. B., \& Verma, S. B. (1992). Comparison of surface fluxes and conductances at two contrasting sites within the Fife area. Journal of Geophysical Research, 97(D17), 18623-18638.

Von Caemmerer, S., \& Farquhar, G. D. (1981). Some relationships between the biochemistry of photosynthesis and the gas exchange of leaves. Planta, 153, 376-387.

Wang, Y. P., \& Leuning, R. (1998). A two-leaf model for canopy conductance, photosynthesis and partitioning of available energy I: model description and comparison with a multilayered model. Agricultural and Forest Meteorology, 91(1/2), 89-111.

Wullschleger, S. (1993). Biochemical limitations to carbon assimilation in $\mathrm{C} 3$ plants-A retrospective analysis of the A/Ci curves from 109 species. Journal of Experimental Botany, 44, 907-920.

Xue, W., Ko, J., Werner, C., \& Tenhunen, J. (2017). A spatially hierarchical integration of close-range remote sensing, leaf structure and physiology assists in diagnosing spatiotemporal dimensions of field-scale ecosystem photosynthetic productivity. Agricultural and Forest Meteorology, 247, 503-519.

Yu, Q., Ren, B. H., Wang, T. Y., \& Sun, S. F. (1998). A simulation of diuranal variations of photosynthesis of C3, plant leaves. Scientia Atmospherica Sinica, 22(6), 867-880.

Zhang, L., Mao, J. F., Shi, X. Y., Ricciuto, D., He, H. L., Thornton, P., et al. (2016). Evaluation of the community land model simulated carbon and water fluxes against observations over ChinaFLUX sites. Agricultural and Forest Meteorology, 226-227, 174-185.

Zhao, D., Zhao, X., Khongnawang, T., Arshad, M., \& Triantafilis, J. (2018). A vis-NIR spectral library to predict clay in Australian cotton growing soil. Soil Science Society of America Journal. https://doi.org/10.2136/sssaj2018.03.0100. 